\title{
Age-related patterns of metabolism and biomass in subterranean tissues of Zostera marina (eelgrass)
}

\author{
George P. Kraemer ${ }^{1, *}$, Randall S. Alberte $\mathrm{e}^{2, * *}$ \\ 'Department of Biology, University of California, Los Angeles, Los Angeles, California 90024, USA \\ ${ }^{2}$ Office of Naval Research, Molecular, Cell and Environmental Biology Program, Arlington, Virginia 22217, USA
}

\begin{abstract}
Production and metabolic features of the rhizomatous marine angiosperm Zostera marina L. (eelgrass) from a subtidal meadow in Monterey Bay, Monterey, California, USA, were examined to assess the impact of the subterranean system on whole plant metabolism. Total subterranean biomass of eelgrass was correlated with above-ground (shoot) biomass. The subterranean system presents a gradient in tissue age, from young (proximal to shoot) to old (distal). While root biomass was constant, indices of metabolic capacity (respiration, soluble carbohydrate content, glutamine synthetase activity) decreased with increasing tissue age. Rhizome internodal biomass and carbohydrate levels were influenced by season and tissue age, and rates of respiration declined with increasing tissue age. The first 4 (youngest) root bundles along the rhizome accounted for $>90 \%$ of total plant $\mathrm{NH}_{4}{ }^{+}$assimilatory potential, while $\mathrm{O}_{2}$ consumption increased linearly with increasing amount of subterranean tissue. A. model of whole plant carbon balance predicted compensation depths (photosynthesis = respiration) for Monterey Bay eelgrass of 4.2 to $11.6 \mathrm{~m}$ depth, given instantaneous shoot $P_{\text {nel }}: R$ ratios of 11 to 4.5 . The model also predicted that small changes in both $P_{\text {ne: }}: R$ and depth (light availability) have the potential to effect large changes in the rate of new tissue production. Although the subterranean tissues constitute 20 to $26 \%$ of plant biomass, carbon consumed by respiration in the subterranean tissue represented $<15 \%$ of gross photosynthetic production $\left(P_{\mathrm{g}}\right)$ at depths $<10 \mathrm{~m}$. At the deep edges of the eelgrass bed, the model predicts that total subterranean respiration increases to $25 \%$ of $P_{\mathrm{g}}$. Since respiration by subterranean tissues represents only 10 to $15 \%$ of total plant respiration, eelgrass carbon balance is strongly controlled by shoot carbon metabolism.
\end{abstract}

\section{INTRODUCTION}

Zostera marina L. (eelgrass) is a regionally important marine angiosperm that can achieve production rates in excess of $4 \mathrm{~g} \mathrm{C} \mathrm{m}^{-2} \mathrm{~d}^{-1}$ (McRoy \& McMillan 1977). Eelgrass is rhizomatous, possessing one or more above-ground shoot bundles that emerge from a linear or branching, subterranean system composed of rhizome segments with 2 bundles of roots at each junction. In order to obtain an understanding of the pro-

\footnotetext{
- Current address: Laboratorio di Ecologia del Benthos, Stazione Zoologica di Napoli, Ischia Porto, I-80077 Naples, Italy

- Address for correspondence and reprints: Hopkins Marine

Station, Pacific Grove, California 93950, USA
}

duction dynamics of this species, knowledge of the functional roles of all the major organ systems is required. The properties of above-ground tissues of seagrasses are generally well documented, including shoot/leaf production (Sand-Jensen 1975, Penhale 1977), characteristics of shoot photosynthesis (Dennison \& Alberte 1985, Zimmerman et al. 1991) and nitrogen assimilation (McRoy \& Goering 1974, Iizumi \& Hattori 1982, Pregnall et al. 1987, Zimmerman et al. 1987). The metabolic features of subterranean tissue and its integrative functional role in whole plant production dynamics, however, are less well known. Aspects investigated have included growth and decomposition of rhizome tissue (Kenworthy \& Thayer 1984, Josselyn et al. 1986, Pangallo \& Bell 1988), metabolic adaptations in response to diel oxic-anoxic 
cycling (Pregnall et al. 1984, Smith et al. 1988) and respiratory carbon demands (Fourqurean \& Zieman 1991). Past studies have also implicitly assumed a homogeneity of physiological performance of subterranean tissues irrespective of age, an assumption violated for leaf tissue (Mazzella \& Alberte 1986).

Whole plant carbon (C) balance has been implicated as a major factor determining the growth and distribution of eelgrass (Dennison \& Alberte 1985, Marsh et al. 1986, Zimmerman et al. 1989). Subterranean tissue in seagrasses can constitute a significant portion of the whole plant biomass (e.g. Hillman et al. 1989). The growth and production of below-ground tissues is supported by shoot photosynthesis, in terms of both $\mathrm{O}_{2}$ and translocated photosynthate (Smith et al. 1984). Metabolism of the subterranean tissue (i.e. respiration and nitrogen assimilation) must be integrated with the metabolic activities of the above-ground shoot to ensure adequate partitioning of $\mathrm{C}$.

Root and rhizome tissues are characterized by different function and metabolism (Zimmerman et al. 1989, Fourqurean \& Zieman 1991). Eelgrass roots play a major role in the assimilation of ammonium (>50\% of whole plant needs; Zimmerman et al. 1987), and rhizomes in eelgrass and other seagrasses serve as carbohydrate storage tissues (Pirc 1985, Smith 1989). The tissue along the rhizome also presents a gradient of increasing age, from the proximal (shoot) to the distal end. New shoots and subterranean segments (each segment composed of a rhizome segment and a pair of root bundles) are synthesized at intervals of approximately 2 wk (Duarte 1991), although plastochrone intervals in eelgrass are under environmental control (Sand-Jensen 1975). The metabolic demands of the subterranean tissue and its contributions to shoot growth in eelgrass are also likely a function of tissue age, as in other plant systems (Jónsdóttir \& Callahan 1988, Kraemer \& Chapman 1991).

The objective of this study was to examine the influence of developmental state on the metabolism of subterranean tissue in Zostera marina, and assess the importance to whole plant carbon balance of any age-dependent metabolism. We examined the seasonality of the allocation of biomass to above-ground (shoot) and below-ground (rhizome and root) tissues, with attention to the coupling of this process between the 2 tissue compartments. We report the influence of tissue age on metabolic competence, using as indicators soluble carbohydrate levels, rates of respiration, and ammonium assimilatory potential (glutamine synthetase activity). Results of the metabolic studies were incorporated into a model predicting biomass-specific growth rates of eelgrass as functions of light availability and instantaneous shoot $P_{\text {net }}: R$ ratios. From the model, we evaluated the $C$ demand by subterranean tissue, relative to gross carbon acquisition.

\section{MATERIALS AND METHODS}

Intact Zostera marina L. plants (Fig, 1) were collected from a subtidal population ( 5 to $7 \mathrm{~m}$ ) located off Del Monte Beach, Monterey Bay, California, USA ( $36^{\circ} 37^{\prime}$ $19^{\prime \prime} \mathrm{N}, 121^{\circ} 54^{\prime} 12^{\prime \prime} \mathrm{W}$ ). Eelgrass were collected during early fall (October 1991), winter (January 1992), and spring (mid-March 1992). Plants were removed from the sediment matrix by fanning away mud and sand, to obtain undamaged individuals, and transported wet in coolers. Plants collected in January were placed in 0.45 $\mu \mathrm{m}$ filtered seawater $\left(14^{\circ} \mathrm{C}\right)$ and held for 2 to $4 \mathrm{~h}$ before metabolic measurements. Plant tissues were divided into above-ground shoot (including the meristematic zone between the leaves and rhizome), subterranean root and rhizome compartments. Rhizome and accompanying root tissue at the distal end of the subterranean axis that was soft and decaying was discarded. Rhizome and root biomass was further subdivided into tissues from each subterranean segment (Fig. 1). All portions were weighed (fresh weight, FW) and frozen $\left(-20^{\circ} \mathrm{C}\right)$.

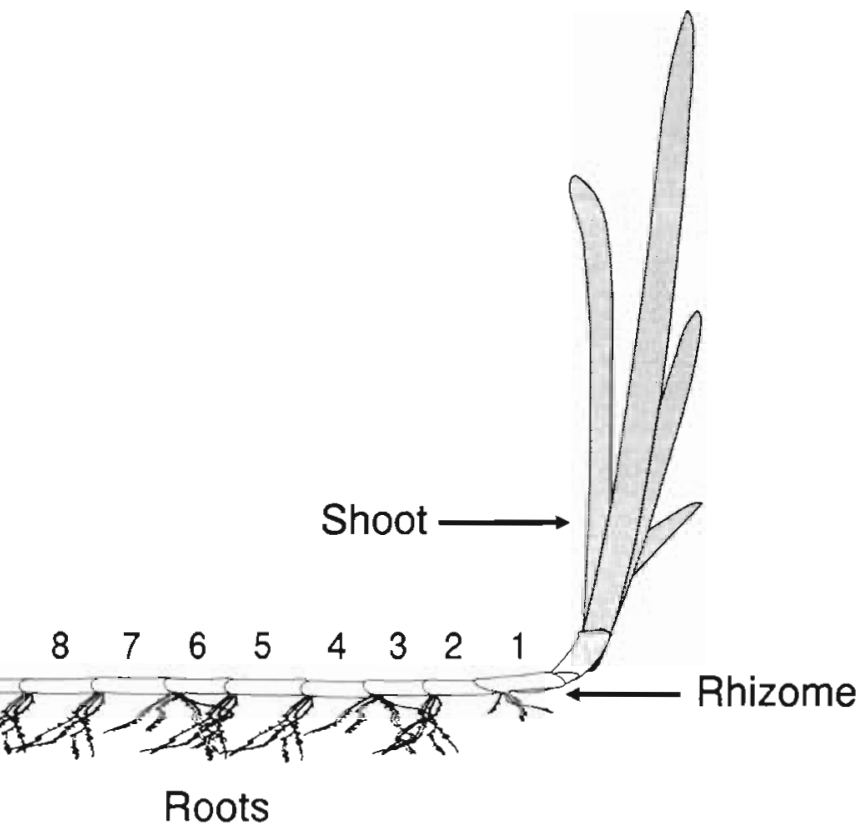

Fig. 1. Zostera marina (eelgrass) morphology. Subterranean segments are numbered in increasing age from youngest (segment 1) to oldest (up to segment 12) 
Table 1. Carbon balance model for Zostera marina. Irradiances predicted at 15 min intervals during an 8 h photosynthetic period (Eq. 1) were used to predict submarine irradiances at depths ranging from 3 to $12 \mathrm{~m}$ (Eq. 2). Depth-and time-specific irradiances were then used to predict gross photosynthetic rate (Eq. 3). Photosynthetic oxygen production and respiratory consumption by each tissue compartment were converted to carbon (assuming photosynthetic and respiratory quotients of 1.2 and 1.0 , respectively), and summed over $24 \mathrm{~h}$ to estimate net daily C gain, which was converted to dry weight and then to wet weight (see below) to predict daily biomass-specific growth rates. Biomass and metabolic parameters were derived from January measurements, except for $\mathrm{C}$ : dry weight ratios which were performed in December

Eq. 1: $I_{t}=I_{\max } \sin (t)$, where $I_{t}=$ irradiance at time $t\left(\mu \mathrm{mol}\right.$ photons $\left.\mathrm{m}^{-2} \mathrm{~s}^{-1}\right) ; t=0$ to $8 \mathrm{~h}_{i} I_{\max }=$ noontime irradiance maximum $\left(1500 \mu \mathrm{mol}\right.$ photons $\left.\mathrm{m}^{-2} \mathrm{~s}^{-1}\right)$

Eq. 2: $I_{d, t}=\left(I_{l} \times\right.$ surface transmittance $) \mathrm{e}^{-k z}$, where $I_{d, l}=$ irradiance at depth $d$ at time $t_{i}$ surface transmittance $=85 \%$; $k=$ attenuation coefficient $\left(0.25 \mathrm{~m}^{-1}\right) ; z=\operatorname{depth}(\mathrm{m})$

Eq. 3: $P_{g, t}=P_{\max }\left[I_{d, t} /\left(I_{k}+I_{d, t}\right)\right]$, where $P_{g, l}=$ gross photosynthesis at time $t\left(\mu \operatorname{mol~O} \mathrm{g} \mathrm{FW}^{-1} \min ^{-1}\right) ; P_{\max }=$ maximum gross photosynthetic rate $\left(0.49 \text { to } 1.18 \mu \mathrm{mol} \mathrm{O} \mathrm{g} \mathrm{FW}^{-1} \mathrm{~min}^{-1} ; \mathrm{P}_{\text {net }}: \mathrm{R} \text { ratios }=4 \text { to } 11\right)_{i} I_{k}=$ irradiance that drives photosynthesis at half of maximum rate $\left(100 \mu\right.$ mol photons $\left.\mathrm{m}^{-2} \mathrm{~s}^{-1}\right)$

Shoot respiration: $0.089 \mu \mathrm{mol} \mathrm{O}_{2} \mathrm{~g} \mathrm{FW}^{-1} \mathrm{~min}^{-1}$ (Zimmerman et al. 1989)

[Root + rhizome] aerobic respiration: $0.25 \mu \mathrm{mol} \mathrm{O} \mathrm{min}^{-1}$ (this study, 8 segments; assumed aerobic when $I_{d, l}>I_{k}$ )

[Root + rhizome] anaerobic respiration: $0.17 \mu \mathrm{mol} \mathrm{O} \mathrm{min}^{-1}$ [67\% of aerobic rates (Smith 1989); assumed anaerobic when $I_{d, l}<I_{k}$ ]

Photosynthetic quotient: 1.2 (McRoy \& McMillan 1977)

Respiratory quotient: 1.0 (sucrose as sole respiratory substrate)

\begin{tabular}{lccc} 
& Root & Rhizome & Shoot \\
\hline Dry weight : wet weight ratio (g g ${ }^{-1}$; this study) & 0.16 & 0.15 & 0.19 \\
Carbon : dry weight ratio ( $\mathrm{g} \mathrm{g}^{-1}$; this study) & 0.29 & 0.37 & 0.38 \\
\hline
\end{tabular}

Soluble carbohydrates in root and rhizome tissue (collected in January 1992) were measured according to Yemm \& Willis (1965). Extracts were stabilized against bacterial degradation by adding sodium azide $(0.02 \%, w / v)$.

Rates of aerobic respiration were measured in the distal $2 \mathrm{~cm}$ of each root bundle, and $1 \mathrm{~cm}$ of each rhizome segment (collected in January). Excised segments were placed into $0.45 \mu \mathrm{m}$ filtered seawater in a temperature-controlled $\mathrm{O}_{2}$ electrode chamber (Rank Bros.). The $\mathrm{O}_{2}$ concentrations (initially 160 to $180 \%$ of air-saturated seawater at $15^{\circ} \mathrm{C}, 33 \%$ ) were monitored for $15 \mathrm{~min}$, after which tissue was removed and fresh weight recorded. Studies of other seagrass species suggest that shoot photosynthesis raises lacunal (and hence tissue) $\mathrm{O}_{2}$ levels above saturated seawater values (Roberts \& Moriarty 1987, Carlson et al. 1988). Respiration by the subterranean tissues of eelgrass also reaches maximal levels at 150 to $200 \%$ air-saturated seawater (Zimmerman et al. 1989), so estimates of the respiratory $C$ consumption are conservative maxima.

Glutamine synthetase (GS) activity was measured in roots of plants collected in January. The transferase assay, outlined by Pregnall et al. (1987), was employed, and the volumes of the assay were reduced to $1.5 \mathrm{ml}$.

Statistical comparisons of data were made using analysis of variance (ANOVA) or Student's t-test procedures, as appropriate. Data were ln-transformed to meet the requirement of homogeneity of variances. Least Significant Difference (LSD) post-hoc tests were employed following ANOVA to rank mean values. Untransformed means and standard deviations are presented in the text, tables, and figures.

To examine the impacts of above- and below-ground tissues on the balance of C production and consumption, a numerical model was constructed using parameter values provided in Table 1 . The winter model of Zostera marina growth combines estimated submarine irradiance and a photosynthesis-irradiance relationship to predict daily $\mathrm{C}$ gain. Light was varied sinusoidally over an $8 \mathrm{~h}$ day with a noon maximum of $1500 \mu \mathrm{mol}$ photons $\mathrm{m}^{-2} \mathrm{~s}^{-1}$, and surface transmission and the water column attenuation coefficient $(k)$ were set at $85 \%$ and $0.25 \mathrm{~m}^{-1}$, respectively (Monterey Bay Aquarium Research Department unpubl. data). A hyperbolic photosynthesis-irradiance relationship $\left(P_{\mathrm{g}}=P_{\max }\left[I /\left(I_{k}+I\right)\right]\right)$ was employed to estimate gross photosynthetic $\mathrm{O}_{2}$ production during $15 \mathrm{~min}$ intervals over the $8 \mathrm{~h}$ illumination period, using corresponding irradiance values for depths ranging from 3 to $12 \mathrm{~m}$. We scaled shoot photosynthesis to respiration, multiplying shoot respiration $\left(0.098 \mu \mathrm{mol} \mathrm{O} \mathrm{g} \mathrm{FW}^{-1} \mathrm{~min}^{-1}\right.$; Zimmerman et al, 1989 ) by $P_{\text {net }}: R$ values of 4 to 11 , The $\mathrm{O}_{2}$ production was converted to $\mathrm{C}$ assuming a photosynthetic quotient of 1.2. Respiration was estimated for each tissue individually. Shoot respiration was assumed constant over each $24 \mathrm{~h}$ day. Both root and rhizome respiration rates were estimated from mea- 
surements presented in this paper. These tissues were assumed to respire aerobically when $I>I_{k}$, and anaerobically ( $67 \%$ of aerobic levels; Smith 1989) when $I<$ $I_{k}$. Sucrose is the major stored carbohydrate; we assumed a respiratory quotient of 1.0 when converting respiratory $\mathrm{O}_{2}$ consumption to $\mathrm{C}$ consumption. The $\mathrm{C}$ fixed and respired by each tissue were summed to estimate the net $C$ output by an average plant from the Del Monte Beach population in January $(21 \mathrm{~g}$ FW shoot tissue, possessing 8 subterranean segments) at depths between 3 and $12 \mathrm{~m}$. The $\mathrm{C}$ output was converted to specific growth rate $\left(\% \mathrm{~d}^{-1}\right)$, given carbon/dry weight ratios $\left(\mathrm{g} \mathrm{g}^{-1}\right)$ measured for each tissue, using dry weight-fresh weight conversions (Table 1), and net fixed $\mathrm{C}$ was distributed among the 3 tissue compartments proportional to their dry weight biomass. Respiratory $\mathrm{C}$ consumption by the subterranean tissues was also summed and presented as a percent of gross photosynthetic $\mathrm{C}$ fixation.

\section{RESULTS}

The subterranean tissue of Zostera marina from Del Monte Beach averaged $26 \pm 9 \%$ of the whole plant biomass of non-reproductive individuals and $20 \pm 6 \%$ of those individuals possessing reproductive stalks (March only). The biomass of the subterranean tissue was related to the above-ground shoot biomass (Fig. 2). Although the proportions of the 3 tissue compartments (shoot, root, and rhizome) did not vary greatly with season (Fig. 3), the absolute biomass (per plant) of each compartment was significantly affected (Table 2). The average biomass of each tissue compartment decreased from summer to winter. Shoot and root compartments increased into the spring season, although rhizome biomass lagged slightly behind, and

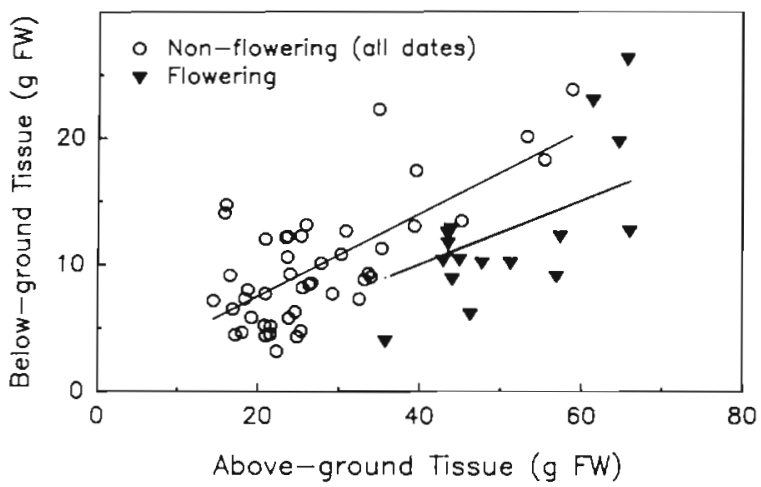

Fig. 2. Zostera marina. Relationship between above-ground tissue ( $\mathrm{g}$ FW shoot biomass) and below-ground tissue ( $\mathrm{g}$ FW rhizome + root). Values for non-flowering plants from different seasons (Oct, Jan, and Mar) were pooled $\left(n_{\mathrm{fl}}=16, n_{\mathrm{nfl}}=46\right)$

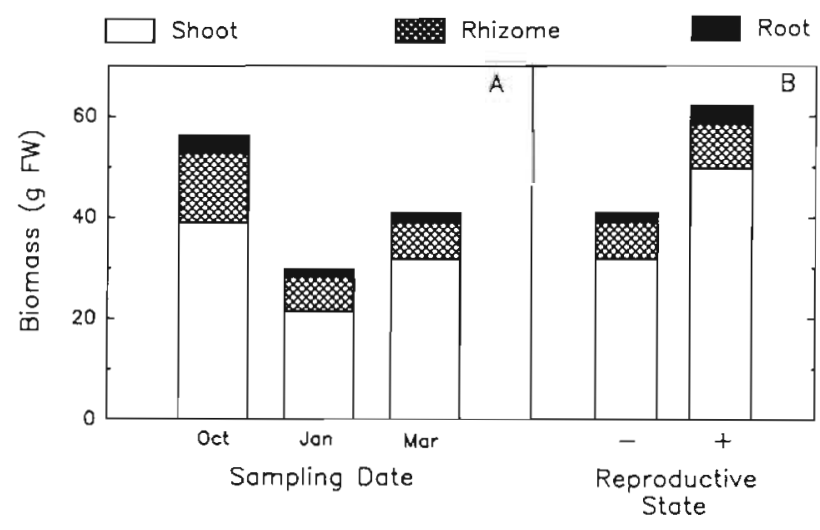

Fig. 3. Zostera marina. Biomass distribution (per plant) (A) Average root, rhizome, and shoot biomass over 3 seasons; $\mathrm{n}_{\mathrm{Oct}}=8, \mathrm{n}_{\text {Jan }}=19, \mathrm{n}_{\mathrm{Mar}}=35$. (B) Data for March, subdivided into flowering $(+)$ and non-flowering $(-)$ plants $\left(\mathrm{n}_{\mathrm{n}}=16, \mathrm{n}_{\mathrm{n} \Omega}=19\right)$

Table 2. Zostera marina. Results of 1-way analyses of variance of shoot, rhizome, and root biomass as a function of sampling season. Biomass values given are averages ( $\pm 1 \mathrm{SD}$ ) for individual plants. Different superscripts indicate statistically different mean values for each tissue type (LSD post-hoc tests; $p<0.05$ ). Reproductive plants (found in March only) were not included in the analysis

\begin{tabular}{|c|c|c|c|c|c|c|}
\hline \multicolumn{7}{|c|}{ Biomass (g FW per plant) } \\
\hline Season & \multicolumn{2}{|c|}{ Shoot } & \multicolumn{2}{|c|}{ Rhizome } & Root & $n$ \\
\hline October & \multicolumn{2}{|c|}{$38.9^{\mathrm{a}}(27.4)$} & \multicolumn{2}{|c|}{$14.0^{\circ}(7.9)$} & $3.4^{a}(1.9)$ & 9 \\
\hline January & \multicolumn{2}{|c|}{$21.4^{\mathrm{b}}(5.7)$} & \multicolumn{2}{|c|}{$6.9^{b}(3.4)$} & $1.4^{\mathrm{b}}(0.5)$ & 19 \\
\hline March & \multicolumn{2}{|c|}{$31.7^{\mathrm{a}}(10.4)$} & \multicolumn{2}{|c|}{$7.5^{b}(3.6)$} & $2.0^{\mathrm{c}}(0.9)$ & 19 \\
\hline \multicolumn{7}{|l|}{ ANOVA } \\
\hline Tissue & Effect & SS & df & MS & $F$ & $\mathrm{p}$ \\
\hline \multirow[t]{2}{*}{ Shoot } & Season & 1.92 & 2 & 0.959 & 8.23 & 0.00123 \\
\hline & Error & 5.12 & 44 & 0.116 & & \\
\hline \multirow[t]{2}{*}{ Rhizome } & Season & 3.21 & 2 & 1.61 & 6.80 & 0.00301 \\
\hline & Error & 10.39 & 44 & 0.24 & & \\
\hline \multirow[t]{2}{*}{ Root } & Season & 4.50 & 2 & 2.25 & 13.6 & 0.0001 \\
\hline & Error & 7.26 & 44 & 0.165 & & \\
\hline
\end{tabular}

Table 3. Zostera marina. Student's t-tests comparing shoot, rhizome, and root biomass as a function of reproductive state $\left(-\right.$, non-reproductive shoots ${ }_{i}+$, reproductive shoots, data from March only). Biomass values given are averages ( \pm 1 SD). $\left(\mathrm{n}_{\text {non-reproductive }}=19, \mathrm{n}_{\text {reproductive }}=16\right)$

\begin{tabular}{|c|c|c|c|c|}
\hline Tissue & $\begin{array}{l}\text { Reproductive } \\
\text { shoot }\end{array}$ & $\begin{array}{c}\text { Biomass } \\
\text { (g FW) }\end{array}$ & $t$-value & $p$-value \\
\hline Shoot & $\begin{array}{l}- \\
+\end{array}$ & $\begin{array}{l}31.7(10.4) \\
49.7(11.6)\end{array}$ & 4.86 & $<0.001$ \\
\hline Rhizome & $\begin{array}{l}- \\
+\end{array}$ & $\begin{array}{l}7.5(3.6) \\
8.9(4.6)\end{array}$ & 0.96 & 0.344 \\
\hline Root & $\begin{array}{l}- \\
+\end{array}$ & $\begin{array}{l}1.95(0.86) \\
3.58(1.94)\end{array}$ & 3.86 & $<0.001$ \\
\hline
\end{tabular}




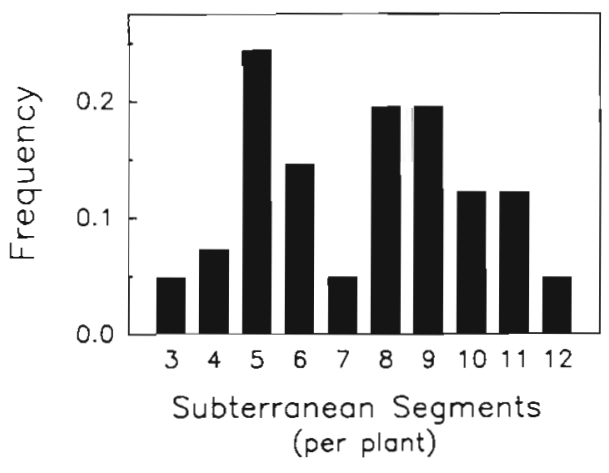

Fig. 4. Zostera marina. Frequency distribution of number of subterranean segments per plant $(n=53)$

whole plant biomass increased sharply concurrent with the production of reproductive shoots (Fig. 3). Shoot and root biomasses of flowering plants (March) were significantly greater $(50 \%)$ than those of nonflowering ones during the same period (Table 3). The extent of subterranean tissue for each plant varied from 3 to 12 segments plant ${ }^{-1}$ (Fig. 4). The average eelgrass plant in the Del Monte Beach population possessed 8 segments.

Root biomass did not change along the age gradient, averaging $0.18 \pm 0.12 \mathrm{~g} \mathrm{FW} \mathrm{segment}^{-1}$ (Fig. 5). Rhizome biomass was less variable than root biomass, averaging $0.76 \pm 0.28 \mathrm{~g} \mathrm{FW}$ for the first 4 segments. In those plants with extensive underground systems, rhizome segment biomass was positively correlated with age for segments 5 to 12 ( $\mathrm{r}=0.42$, $\mathrm{p}<0.05$ ).

Root and rhizome tissue differed in both the absolute concentrations of soluble carbohydrates (ca 90\% sucrose; Smith 1989), and in relationship to tissue age (Fig. 6). Carbohydrate levels decreased exponentially in roots from about $20 \mu \mathrm{mol}$ sucrose equivalents $\mathrm{g} \mathrm{FW}^{-1}$ in the 1 st segment, to between 5 and $10 \mu \mathrm{mol}$ $\mathrm{g} \mathrm{FW}^{-1}$ for the remaining segments (regression analysis of In-transformed data; $\mathrm{p}<0.01, \mathrm{r}^{2}=0.15$ ). The concentration of soluble carbohydrates in rhizome tissue was approximately 10 times greater than in root tissue. Rhizome carbohydrate levels were significantly higher in intermediate (nos. 2 to 9 ) segments than in the oldest (nos. 11, 12) segments (ANOVA $F=5.83$, LSD posthoc tests $p<0.05$ ).

Respiration rates in root tissue (Fig. 7) declined exponentially with tissue age, from $0.18 \mu \mathrm{mol} \mathrm{O}_{2} \mathrm{~g} \mathrm{FW}^{-1}$ $\mathrm{min}^{-1}$ in the 1st segment, to approximately $0.07 \mu \mathrm{mol}$ $\mathrm{O}_{2} \mathrm{~g} \mathrm{FW}^{-1} \mathrm{~min}^{-1}$ in the 12 th (regression analysis of $\mathrm{ln}$ transformed data; $\mathrm{p}<0.05, \mathrm{r}^{2}=0.13$ ). Respiration in rhizome tissue was approximately 1 order of magnitude less than in the roots. Rates decreased linearly with increasing tissue age from ca 20 to $8 \mathrm{nmol} \mathrm{O}_{2}$

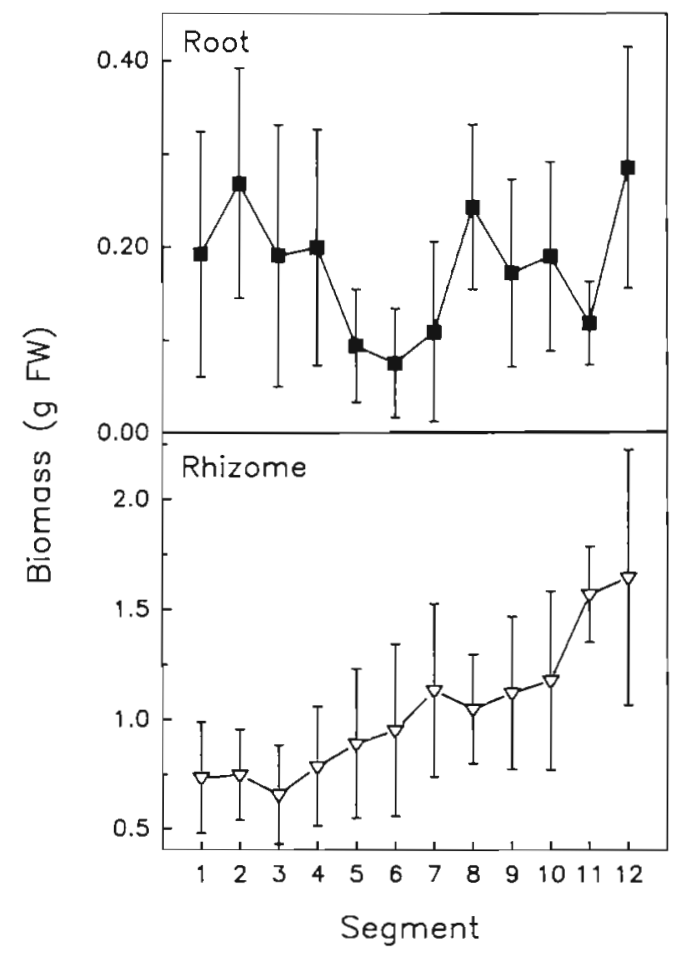

Fig. 5. Zostera marina. Biomass (g FW per plant) as a function of subterranean segment for root $(n=11)$ and rhizome tissue $(\mathrm{n}=11)$. Subterranean tissue was divided into segments (see Fig. 1) and the weights of rhizome and root tissue of each segment were measured separately (tissue collected in January)

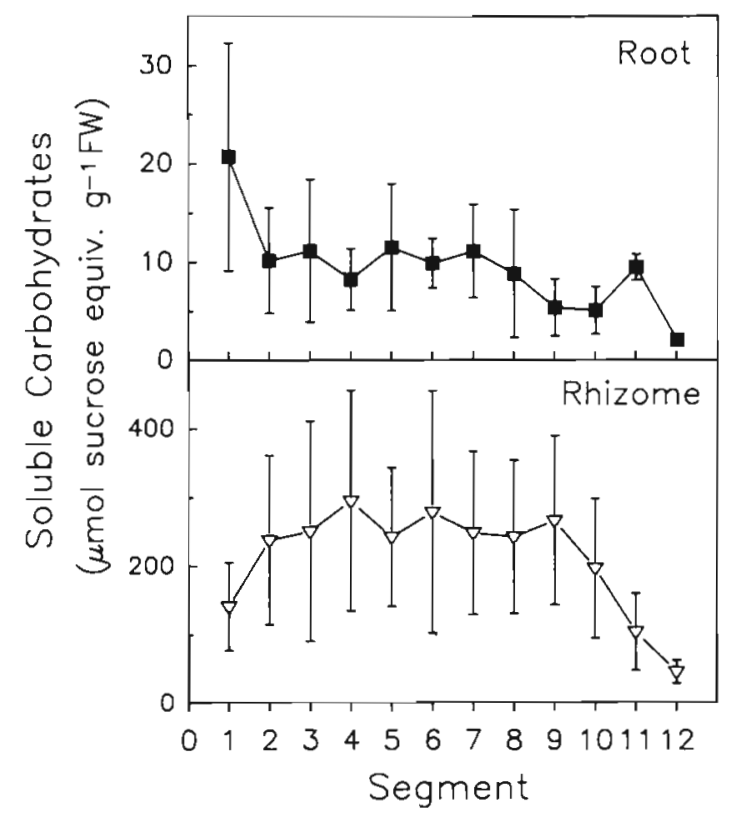

Fig. 6. Zostera marina. Soluble carbohydrate concentration

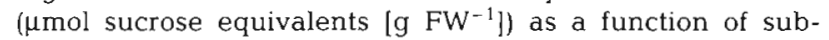
terranean segment in root $(n=8)$ and rhizome tissue $(n=6)$ collected in January 


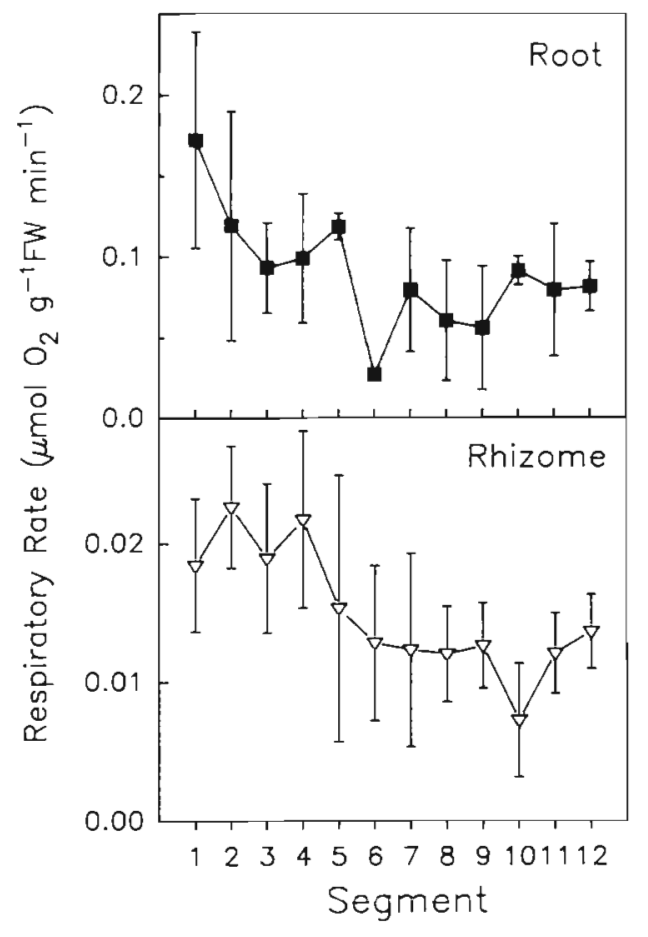

Fig. 7. Zostera marina. Aerobic respiration rate $\left(\mu \mathrm{mol} \mathrm{O}_{2} \mathrm{~g}\right.$ $\mathrm{FW}^{-1} \mathrm{~min}^{-1}$ ) as a function of subterranean segment in root $(n=5)$ and rhizome tissue $(n=5)$ collected in January

g FW ${ }^{-1} \min ^{-1}\left(p<0.01, r^{2}=0.22\right)$. There were no differences between respiratory rates of the meristematic zone (the stem analog of Thalassia testudinum) and adjacent rhizome tissue (data not shown).

Biomass ( $g$ FW) and aerobic respiratory rate (nmol $\mathrm{O}_{2} \mathrm{~g} \mathrm{FW}^{-1} \mathrm{~min}^{-1}$ ) data were combined to estimate the $\mathrm{O}_{2}$ demand by each segment of subterranean tissue. These values were converted to $\mathrm{C}$ units, assuming that only sucrose (ca $90 \%$ of soluble carbohydrates) was respired $(R Q=1.0)$. The $C$ demand by root tissue was driven by differences in respiration (Fig. 8; biomass did not vary appreciably along the age gradient), decreasing exponentially from 40 to approximately $15 \mathrm{nmol}$ sucrose $\min ^{-1}$ by the 3 rd or 4 th segment. In rhizome tissue, however, $\mathrm{C}$ consumption was independent of internodal age. With the exception of the first 2 root bundles, roots and rhizomes of each subterranean unit consumed sucrose at about the same rate (10 to

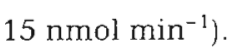

The activity of GS, a measure of ammonium assimilatory potential, also decreased exponentially with root tissue age (regression analysis of ln-transformed data; $\mathrm{p}<0.001, \mathrm{r}^{2}=0.17$ ), declining from about $0.20 \mathrm{mmol}$ $\mathrm{NH}_{4}^{+}$assimilated $\mathrm{g} \mathrm{FW}^{-1} \mathrm{~min}^{-1}$ to minimal levels (<0.02 mmol $\mathrm{g} \mathrm{FW}^{-1} \mathrm{~min}^{-1}$ ) by the 5 th root bundle (Fig. 9).

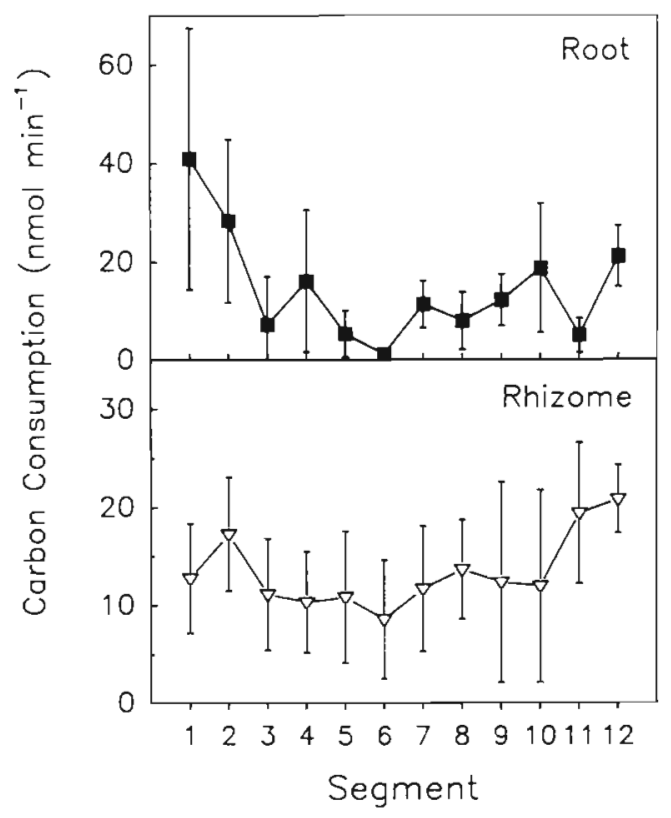

Fig. 8. Zostera marina. Carbon consumption (nmol $\left.\mathrm{min}^{-1}\right)$ as a function of subterranean segment in root $(n=5)$ and rhizome tissue $(n=5)$ collected in January

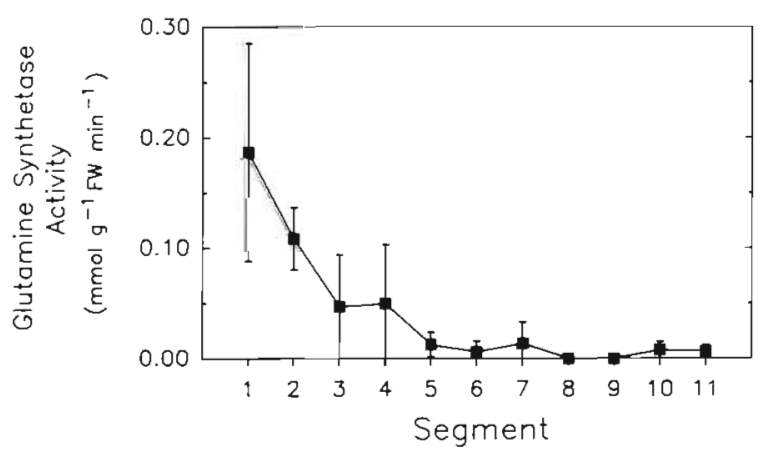

Fig. 9. Zostera marina. Glutamine synthetase activity (mmol $\mathrm{NH}_{4}{ }^{+}$assimilated $\mathrm{g} \mathrm{FW}^{-1} \mathrm{~min}^{-1}$ ) of root tissue as a function of subterranean segment in plants $(n=5)$ collected in January

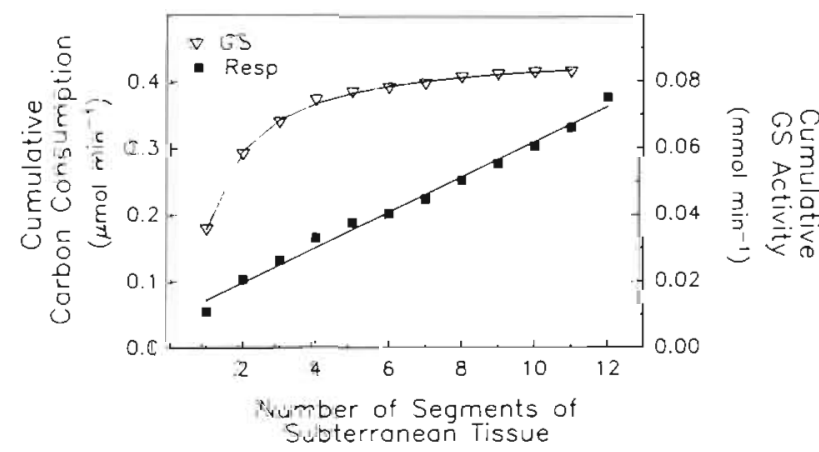

Fig. 10. Zostera marina. Estimated cumulative carbon con-

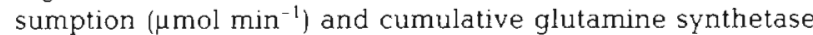
activity (mmol $\mathrm{NH}_{4}^{+}$assimilated $\mathrm{min}^{-1}$ ) as a function of total subterranean tissue 


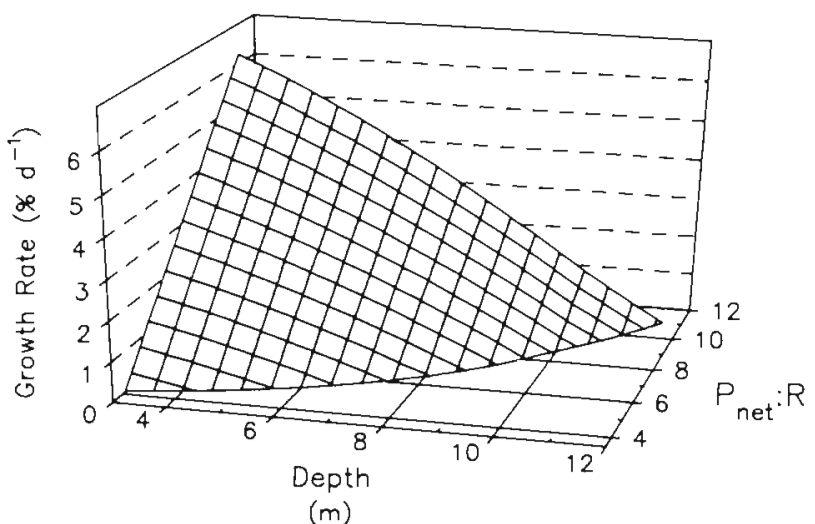

(m)

Fig. 11. Zostera marina. Predicted biomass-specific growth rates $\left(\% \mathrm{~d}^{-1}\right)$ for as a function of depth (irradiance) and instantaneous shoot $P_{\text {net }}: R$. Growth rates calculated for average plant collected in January (8 subterranean segments, $21 \mathrm{~g} \mathrm{FW}$ shoot tissuel

To further assess the functional importance of the subterranean tissues to whole plant $\mathrm{C}$ balance, we estimated the cumulative $\mathrm{C}$ demand and nitrogen assimilatory potential along the subterranean portion of plants (Fig. 10). Total C consumption by root + rhizome tissue rose linearly along the age gradient. On the other hand, cumulative GS activity rapidly plateaued, with $90 \%$ of the total plant ammonium assimilatory potential accounted for by only the first 4 root bundle segments.

The model of whole plant $\mathrm{C}$ balance demonstrated the strong effect of the instantaneous shoot net photosynthesis: respiration $\left(P_{\text {net }}: R\right)$ ratio on whole plant $\mathrm{C}$ balance (Fig. 11). The model predicted, for example, that photosynthesis, driven by the irradiance available at $4.2 \mathrm{~m}$ depth, meets respiratory $\mathrm{C}$ demands of the whole plant (exclusive of any growth), given a $P_{\text {net }}: R$ ratio of 4.5 , while photosynthesis at $11.6 \mathrm{~m}$ depth would satisfy whole plant respiratory demands if the $P_{\text {net }}: R$ ratio were 11 (Table 4). A specific growth rate of $1 \% \mathrm{~d}^{-1}(1$ to $2 \%$ measured in the field and laboratory culture; Dennison \& Alberte 1985, Kraemer \& Alberte unpubl.), could be maintained in waters no deeper than 3.0 and $10.3 \mathrm{~m}$ for $P_{\text {nel }}: R$ ratios of 6 and 11 respectively. When the subterranean tissue of the model plant was increased from 8 to 12 segments, the predicted compensation depths (photosynthetic production - whole plant respiratory consumption over $24 \mathrm{~h}$; growth rate $=0 \%$ $\mathrm{d}^{-1}$ ) decrease by only 0.3 to $0.6 \mathrm{~m}$ for a $P_{\text {net }}: R$ range of 6 to 11 (data not shown).

The $\mathrm{C}$ demand of the subterranean tissue represents a variable percentage of $C$ flux into the plant (Fig. 12), but was $<15 \%$ when $P_{\text {net }}: R>7$ and depth $<10 \mathrm{~m}$. Both depth (irradiance) and shoot $P_{\text {net }}: R$ affect the relative $C$ demand by subterranean tissue, with
Table 4. Zostera marina. Maximum depths (m) predicted by whole plant carbon model when submarine irradiance produces biomass-specific growth rates of 0 to $3 \% \mathrm{~d}^{-1}$ (given instantaneous shoot $P_{\text {nel }}: R$ ratios of 4 to 11 , and a plant from the January Del Monte Beach population with average shoot biomass and 8 subterranean segments $[21 \mathrm{~g}$ shoot, $1.4 \mathrm{~g}$ root, $6.9 \mathrm{~g}$ rhizome biomass])

\begin{tabular}{|c|c|c|c|}
\hline \multirow{2}{*}{$P_{\text {net }}: R$} & \multicolumn{3}{|c|}{ Growth rate $\left(\% \mathrm{~d}^{-1}\right)$} \\
\hline & $0 \%$ & $1 \%$ & $3 \%$ \\
\hline 4 & $<3^{\circ}$ & $<3$ & $<3$ \\
\hline 6 & 7.4 & 4.8 & $<3$ \\
\hline 8 & 9.9 & 7.8 & 4.4 \\
\hline 10 & 11.0 & 9.6 & 6.6 \\
\hline 11 & 11.6 & 10.2 & 7.5 \\
\hline \multicolumn{4}{|c|}{$\begin{array}{l}\text { aShallower than observed, } 3.1 \mathrm{~m} \text { depth nearshore limit at } \\
\text { site }\end{array}$} \\
\hline
\end{tabular}

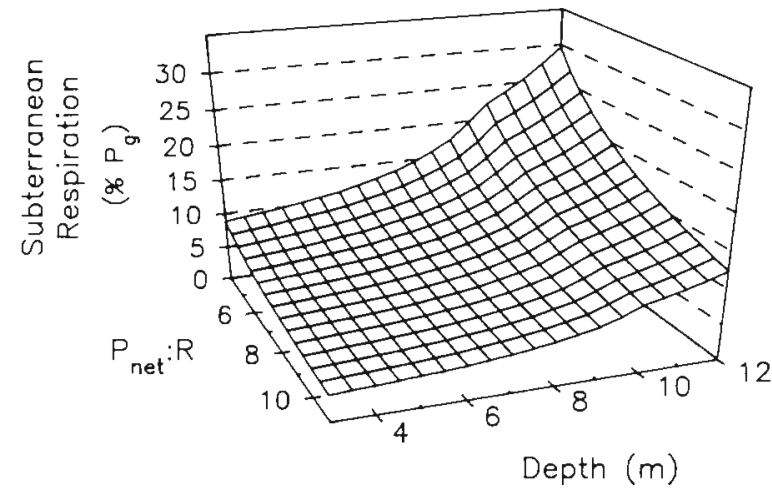

Fig. 12. Zostera marina. Carbon demand of subterranean tissues (percent of gross photosynthetic production, i.e. total carbon fixed), as a function of depth (irradiance) and instantaneous shoot $P_{\text {net }}: R$. Carbon demand calculated for average plant collected in January ( 8 subterranean segments, 21 g FW shoot tissue)

marked effects for plants growing at depth with low shoot $P_{\text {net }}: R$. That is, as total $C$ influx is reduced by irradiance limitation, the relative amount of the $C$ influx that must be devoted to the respiration of subterranean tissue increases disproportionately. Additionally, when the subterranean tissue compartment is increased to 12 segments, the relative respiratory $\mathrm{C}$ demand increases (data not shown), though it still generally represents $<25 \%$ of $\mathrm{C}$ influx into the plant $\left(P_{g}\right)$. The discontinuity in the surface derives from the initial assumption that subterranean tissue functions anaerobically when $I<I_{k}$. This condition is met for increasing periods as maximum irradiance decreases at depths $<10 \mathrm{~m}$. However, at depths $\geq 10 \mathrm{~m}$, the model assumes that subterranean tissue always functions anaerobically. Hence, Fig. 12 represents a combination of 2 surfaces. 


\section{DISCUSSION}

\section{Biomass allocation}

The subterranean tissue of Zostera marina is a significant biomass compartment, ranging between 20 and $26 \%$ of the total plant biomass. Consideration of this compartment is important when modeling the production dynamics, or assessing the contribution by eelgrass to organic matter deposition in coastal ecosystems. The relationship between above- and below-ground biomass, although variable, was independent of growth season in non-flowering plants in Monterey Bay. This suggests that the metabolism and growth of above- and below-ground tissues is coupled, in congruence with an earlier study of eelgrass production at Woods Hole, Massachusetts, USA (Dennison \& Alberte 1986). At another level, integration between tissue compartments is evident in the relative constancy of the proportions of shoot, rhizome, and root tissue during late summer, winter, and spring periods. This integration occurs in plants with a wide range of subterranean biomass, as plants collected here possessed subterranean systems that ranged from 3 to 12 segments. The scarcity of plants with 7 subterranean segments is puzzling, possibly deriving from the loss from the population of juvenile root tissue during a stormy episode. It is unlikely that the bimodality represents 2 year classes because the segments account for only 2 to 4 wk of growth (Duarte 1991).

The existence of a seasonal effect on plant biomass is not surprising. The depth distribution and growth of eelgrass is likely limited primarily by light in Monterey Bay, a relatively stenothermal environment (Zimmerman et al. 1991). The lowest plant biomass values here were obtained during January, when light-driven photosynthesis is likely also at a yearly low. Orth \& Moore (1986) and Kerr \& Strother (1990) have reported similar relationships between season and the abundance of both above- and below-ground tissue of Zostera marina from eurythermal environments. However, the allocation of $Z$. marina biomass into above- and belowground tissue compartments varies widely with geographic location. For example, the subterranean tissue of eelgrass from Vellerup Vig (Denmark) represented $57 \%$ of total plant biomass (Sand-Jensen 1975), while below-ground biomass of the Monterey Bay population (this study) averaged $20 \%$ (non-flowering plants), and January values for plants from an intertidal population at Elkhorn Slough, Moss Landing, California (40 km distant) averaged $10 \%$ (Britting et al. unpubl.). It is cleat from this comparison and others (e.g. Duarte 1991) that much phenotypic plasticity in biomass allocation exists for this species. Phenotypic plasticity in amount of subterranean biomass in relation to light availability may be critical to the ability of $Z$. marina to occupy a broad range of environments along most coasts of the Northern Hemisphere.

The root and rhizome compartments allocate biomass differently along the subterranean axis. The rapid establishment of root biomass (ca $0.18 \mathrm{~g}$ FW segment $^{-1}$ ) supports the idea that roots are functionally important in the acquisition of nutrients (Zimmerman et al. 1987), and probably also as anchoring structures. Rhizome segments were of constant biomass (ca $0.68 \mathrm{~g}$ FW) for the first 4 segments, after which biomass per segment increased. Although the data presented here cannot exclude an increase in biomass of rhizome segments over time, it is more likely that rhizome segment biomass reaches a constant value soon after the generation of each segment, and the observed pattern represents an effect of season (amount of photosynthate available for rhizome biosynthesis). Assuming that 2 segments are synthesized each month (Duarte 1991), the largest segments (the 11 th and 12th) were generated during July, and limitation of the production of rhizome biomass did not begin until November. Total rhizome biomass varied significantly with season, ranking October > January $\approx$ March, in agreement with our interpretation. The seasonal and geographic variability in morphometrics is undoubtedly responsible for some of the within-species variability in the architectural indices reported by Duarte (1991).

\section{Metabolic indices}

The pattern in soluble carbohydrate levels (ca $90 \%$ sucrose; Smith 1989) in root tissue was generally mirrored by age-related measures of metabolic capacity or performance, including respiration, GS activity, protein content and synthesis (this study, Kraemer \& Alberte unpubl.). Because root metabolic functions are likely coordinated, this diverse group of metabolic indices probably shows similar patterns. For this reason, we have fitted the data relating root tissue age and metabolism with exponential curves for modeling purposes. Carbohydrate pool sizes also varied seasonally; levels in roots collected in winter (this study) were $36 \%$ less than levels in roots collected during the summer at the same site (June and July; Smith 1989). The levels of carbohydrates in rhizome tissue reflect a more complex situation. Given that the biomass increases in rhizome segments 5 to 12 , the decrease in carbohydrate concentration from segments 10 to 12 likely represents mobilization and translocation of $C$ reserves, and to a lesser extent, utilization to meet tissue respiratory demands. Segments 10 to 12 are not dead (Fig. 7), so it is unlikely that stored carbohydrates are lost through leaching. Thus, it appears that there is parti- 
tioning of function within the rhizome, where young segments are $\mathrm{C}$ stores, while older segments act as $\mathrm{C}$ sources. Ott (1980) suggested that carbohydrate stores in Posidonia oceanica are utilized to support continued rapid growth during winter when light is limiting. If Zostera marina relies on a similar growth strategy, plants possessing few subterranean segments might be at a disadvantage because they lack sufficient reserves of $C$ to maintain high levels of growth during winter.

There is a defined gradient in physiological function along the subterranean axis of eelgrass. It is clear that when modeling the contribution of the subterranean portion to the nitrogen metabolism of the whole plant, one need examine only the first 4 segments, which together constitute approximately $90 \%$ of the ammonium assimilatory potential. However, the respiratory demand (in terms of both shoot-derived $\mathrm{O}_{2}$ and sucrose) continues to increase as the amount of subterranean tissue increases. Therefore, the existence of tissue distal to the 4 th segment implies an importance outside of nitrogen metabolism, which likely includes carbohydrate storage by rhizome segments and anchoring.

These data aiso suggest differences in the physiological lifetimes of the roots and rhizomes. The rate of root respiration and GS activity both decline in a characteristically exponential fashion with increasing tissue age, unlike the pattern for respiration of the rhizomes. Roots exhibit an initial burst of growth and metabolism, while rhizome function decreases over much longer time scales.

\section{Whole plant carbon budget model}

Our model of eelgrass growth as a function of irradiance is the first to consider age-dependency in subterranean metabolism, as well as both aerobic and anaerobic respiratory consumption of $\mathrm{C}$. We assumed a cessation of growth when net $C$ gain becomes zero or negative. Plants may maintain growth, albeit at reduced rates, by mobilizing carbohydrates stored in the rhizomes.

The model predicts compensation depths that lie between 4.2 and $11.6 \mathrm{~m}$ depth for instantaneous shoot net $P_{\text {net }}: R$ ratios of 4.5 to 11 . The lower depth limit of the Del Monte Beach population is approximately $10 \mathrm{~m}$ (Kraemer pers. obs.). If this distributional limit results only from light limitation, the model predicts a $P_{\text {net }}: R$ ratio of 8.5 . This is very close to the average shoot $P_{\text {net }}: R(8.6)$ measured between November and March (1992-93) of plants from a nearby Zostera marina population (Britting et al. unpubl.). For a $P_{\text {net }}: R$ of 8.6 , the model predicts winter growth rates of 0.1 to $5.8 \% \mathrm{~d}^{-1}$ at depths of 11.5 to $3 \mathrm{~m}$, bracketing rates of 1 to $4 \%$ that have been measured in laboratory and field culture (Dennison \& Alberte 1986, Kraemer unpubl.).

The model predicts strong effects of both depth (irradiance) and instantaneous $P_{\text {net }}: R$ on eelgrass growth. Assuming a shoot $P_{\text {net }}: R$ of 8.6 , the predicted growth rate triples from 0.8 to $2.5 \% \mathrm{~d}^{-1}$ when depth decreases from 10.5 to $8.5 \mathrm{~m}$. Likewise, at $5 \mathrm{~m}$ depth, the model predicts specific growth rates of 1.8 to $3.5 \% \mathrm{~d}^{-1}$ for shoot $P_{\text {net }}: R$ of 7 to 9 . Therefore, small changes in either light availability, or instantaneous shoot $P_{\text {net }}: R$, produce significant changes in net daily $\mathrm{C}$ gain. This has the potential to sharply alter eelgrass growth rates, and as a result, produce changes in physical (water motion, light and nutrient availability) and biological aspects (biomass/substrate availability) of the seagrass ecosystem.

The model reveals the disparity in the influences of subterranean and shoot tissue in affecting whole plant $C$ balance, under all but the most light-limited conditions (deep growing plants, low $P_{\text {net }}: R$ ). Subterranean tissue consumes little photosynthate, compared with production by shoots ( $<15 \%$ when depth $<10 \mathrm{~m}$ ), by virtue of the high shoot photosynthetic rates. Additionally, respiration by subterranean tissue constitutes a small portion of total plant respiration (10 to $15 \%$ ). This is in contrast to that reported for the subtropical seagrass Thalassia testudinum, for which respiration by non-photosynthetic tissue comprised $58 \%$ of the total respiratory demand (Fourqurean \& Zieman 1991).

The model has identified several aspects of eelgrass biology that require additional investigation. The role of rhizomes as carbohydrate storage organs, buffering against periods of limited photosynthate production, is unknown. Clearly, rhizomes possess abundant reserves (ca $225 \mu \mathrm{mol}$ sucrose $\mathrm{g} \mathrm{FW}^{-1}$ segment ${ }^{-1}$ vs 15 to $20 \mathrm{nmol}$ sucrose $\mathrm{g}^{-1} \mathrm{FW} \mathrm{min}^{-1}$ consumed in aerobic respiration by the root + rhizome tissue of one segment). If stored $\mathrm{C}$ is readily accessible, those plants with extensive subterranean systems should be competitively superior in environments characterized by short and long episodes of elevated water column turbidity (Zimmerman et al. 1991). For the Monterey Bay population of Zostera marina, the predictive capabilities of the model may be limited by the precision in estimating instantaneous shoot $P_{\text {net }}: R$ values. With the strong influence of shoot photosynthesis, the measured variability of winter $P_{\text {net }}: R$ (coefficient of variation = $19 \%$; Britting et al. unpubl.) translates into a large range of predicted growth rates. Thus, a more precise mechanistic understanding of the integration of metabolic compartments of seagrasses and an elucidation of key controlling pathways will allow refinement of production models, in turn enabling more reliable prediction of depth distributions and production dynamics for 
a broad range of nearshore environments. As such, the carbon balance model should emerge as an important tool for the management of these critical marine resources.

Acknowledgements. We thank J. Coyer, G. Suba, and R. C. Zimmerman for SCUBA diving assistance, and G. Procaccini and A. Cabello for logistical help. D. Anderson (Monterey Bay Aquarium) performed the $\mathrm{C}: \mathrm{H}: \mathrm{N}$ analyses. The manuscript benefited from the suggestions of S. Britting, R. C. Zimmerman, and 3 anonymous reviewers. This work was supported by grants from NSF and NOAA-NERRS.

\section{LITERATURE CITED}

Carlson, P. R., Yarbro, L. A., Sargent, W. B., Arnold, H. A. (1988). Hypoxic stress in Thalassia testudinum: evidence from diurnal changes in rhizome gas composition. EOS 69: 1115

Dennison, W. C., Alberte, R. S. (1985). Role of daily light period in the depth distribution of Zostera marina (eelgrass). Mar. Ecol. Prog. Ser. 25: 51-61

Dennison, W. C., Alberte, R. S. (1986). Photoadaptation and growth of Zostera marina L. (eelgrass) transplants along a depth gradient. J. exp. mar. Biol. Ecol. 98: 265-282

Duarte, C. M. (1991). Allometric scaling of seagrass form and productivity. Mar. Ecol. Prog. Ser. 77: 289-300

Fourqurean, J. W., Zieman, J. C. (1991). Photosynthesis, respiration and whole plant carbon budget of the seagrass Thalassia testudinum. Mar. Ecol. Prog. Ser. 69: $161-170$

Hillman, K., Walker, D. I., Larkum, A. W. D., McComb, A. J. (1989). Productivity and nutrient limitation. In: Larkum, A. W. D., McComb, A. J., Shepherd, S. A. (eds.) Biology of seagrasses: a treatise on the biology of seagrasses with special reference to the Australian region. Elsevier, Amsterdam, p. 635-685

Iizumi, H., Hattori, A. (1982). Growth and organic production of eelgrass (Zostera marina L.) in temperate waters of the Pacific coast of Japan. III. The kinetics of nitrogen uptake. Aquat. Bot. 12: 245-256

Jónsdóttir, I. S., Callahan, T V. (1988). Interrelationships between different generations of interconnected tillers of Carex bigelowii. Oikos 52: 120-128

Jørgensen, N. O. G., Blackburn, T. H., Henriksen, K., Bay, D. (1981). The importance of Posidonia oceanica and Cymodocea nodosa as contributors of free amino acids in water and sediment of seagrass beds. P.S.Z.N. I: Mar. Ecol. 2: $97-112$

Josselyn, M., Fonseca, M., Niesen, T., Larson, R. (1986). Biomass, production, and decomposition of a deep-water seagrass, Halophila decipiens Ostenf. Aquat. Bot. 25: $47-61$

Kemp, W. M., Murray, L., Borum, J., Sand-Jensen, K. (1987). Diel growth in eelgrass, Zostera marina. Mar. Ecol. Prog Ser. 41: 79-86

Kenworthy, W. J., Thayer, G. (1984). Production and decomposition of the roots and rhizomes of seagrasses, Zostera marina and Thalassia testudinum, in temperate and subtropical manine ecosystems. Bull. mar. Sci. 35 363-379

Kerr, E. A., Strother, S. (1990). Seasonal changes in standing crop of Zostera marina in southeastern Australia. Aquat. Bot. 38: 369-376
Kraemer, G. P., Chapman, D. J. (1991). Effects of tensile force and nutrient availability on carbon uptake and cell wall synthesis in blades of juvenile Egregia menziesii (Turn.) Aresch. (Phaeophyta). J. exp. mar. Biol. Ecol. 149: $267-277$

Marsh, J. A., Dennison, W. C., Alberte, R. S. (1986). Effects of temperature on photosynthesis and respiration in eelgrass (Zostera marina L.). J. exp. mar. Biol. Ecol. 101: $257-267$

Mazzella, L., Alberte, R. S. (1986). Light adaptation and the role of autotrophic epiphytes in primary production of the temperate seagrass Zostera marina L. J. exp. Mar. Biol. Ecol 100: $165-180$

McRoy, C. P., Goering, J. J. (1974). Nutrient transfer between the seagrass Zostera marina and its epiphytes. Nature 248 : $173-174$

McRoy, C. P., McMillan, C. (1977). Production ecology and physiology of seagrasses. In: McRoy, C. P., Helfferich, C. (eds.) Seagrass ecosystems: a scientific perspective. Marcel Dekker, Inc., New York, p. 53-88

Orth, R. J., Moore, K. A. (1986). Seasonal and year-toyear variations in the growth of Zostera marina L. (eelgrass) in the lower Chesapeake Bay. Aquat. Bot. 24: $335-341$

Ott, J. A. (1980). Growth and production in Posidonia oceanica (L.) Delile. P.S.Z.N. I: Mar. Ecol. 1: 65-71

Pangallo, R. A., Bell, S. S. (1988). Dynamics of the aboveground and belowground structures of the seagrass Halodule wrightii. Mar. Ecol. Prog. Ser. 43: 297-301

Penhale, P. (1977). Macrophyte-epiphyte biomass and productivity in an eelgrass (Zostera marina L.) community. J. exp. mar. Biol. Ecol. 26: 211-224

Pirc, H. (1985). Growth dynamics in Posidonia oceanica (L.) Delile. I. Seasonal changes of soluble carbohydrates, starch, free amino acids, nitrogen, and organic anions in different parts of the plant. P.S.Z.N. I: Mar. Ecol. 6: $141-165$

Pregnall, A. M., Smith, R. D., Alberte, R. S. (1987). Glutamine synthetase activity and free amino acid pools of eelgrass (Zostera marina L.) roots. J. exp. mar. Biol. Ecol. 106: $211-228$

Pregnall, A. M., Smith, R. D., Kursar, T., Alberte, R. S (1984). Metabolic adaptation of Zostera marina (eelgrass) to diurnal periods of root anoxia. Mar. Biol. 83: $141-147$

Roberts, D. G., Moriarty, D. J. W. (1987). Lacunal gas discharge as a measure of productivity in the seagrasses Zostera capricorni, Cymodocea nodosa, and Syringodium isoetifolium. Aquat. Bot. 28: 143-160

Sand-Jensen, K. (1975). Biomass, net production, and growth dynamics in an eelgrass (Zostera marina L.) population in Vellerup Vig, Denmark. Ophelia 14: 185-201

Smith, R. D. (1989). Anaerobic metabolism in the roots of the seagrass Zostera marina L. Ph.D. dissertation, University of Chicago

Smith, R. D., Dennison, W. C., Alberte, R. S. (1984). Role of seagrass photosynthesis in root aerobic processes. Plant Physiol. 74: 1055-1058

Smith, R. D., Pregnall A. M., Alberte, R. S. (1988). Effects of anaerobiosis on root metabolism of Zostera marina (eelgrass): implications for survival in reducing sediments. Mar. Biol. 98: 131-141

Yemm, E. W. Willis, A. J. (1965). The estimation of carbohydrates in plant extracts by anthrone. Biochem. J. 57: $508-514$

Zimmerman, R. C., Reguzzoni, J. L., Wylie-Echeverria, S., Josselyn, M., Alberte, R. S. (1991). Assessment of en- 
vironmental suitability for growth of Zostera marina L. (eelgrass) in San Francisco Bay. Aquat. Bot. 39: $353-366$

Zimmerman, R. C., Smith, R. D., Alberte, R. S. (1987). Is growth of eelgrass nitrogen limited? A numerical simulation of the effects of light and nitrogen on the growth

This article was presented by G. W. Thayer, Beaufort,

N. Carolina, USA dynamics of Zostera marina. Mar Ecol. Prog. Ser. 41: $167-176$

Zimmerman, R. C. Smith, R. D., Alberte, R. S. (1989). Thermal acclimation and whole-plant carbon balance in Zostera marina L. (eelgrass). J. exp. mar. Biol. Ecol. 130: $93-109$

Manuscript first received: August 14, 1992

Revised version accepted: February 5, 1993 